\title{
Sobre a beleza de Sílvio Coelho dos Santos
}

\section{Rafael José de Menezes Bastos}

Pesquisador CNPq / Unıversıdade Federal de Santa Catarna Florıanopolıs, Brasil rafael bastos@pq cnpq br

Conhecı Súlvıo, se não me falha a memorıa, em 1978 Eu traba lhava na Fundação Nacıonal do Índıo (Funaı) desde 1975, que vıvıa a sua Prımavera de Praga, sob a presıdêncıa do General Ismarth de Araujo Oliveiral ${ }^{1}$ Eu havia sido indıcado pelo Gal Ismarth para ocupar a posıção de representante da FUNAI no Projeto Urugual Os Barramentos e os Índıos, coordenado por Sılvıo O projeto envolvia a Unıversıdade Federal de Santa Catarına, a Eletrosul Centraıs Eletricas $S$ A, e a Funaı Pıoneiramente - e não somente no Brasıl -, ele tinha como objeto os umpactos socioculturais e ambientais sobre as terras e sociedades indígenas provocados pela construção dos barramentos então planejados pela Eletrosul no curso do Rıo Uruguaı Alı começaram minhas relações com Sılvio - e com Florıanópolıs - sob o sıgno de uma imensa e duradoura admuração Naquela posição, lembro-me que vım a Florıanópolıs umas duas vezes - quando em defınıtıvo me encanteı com a cıdade - Sílvıo tendo ıdo a Funaı em Brasílı maıs ou menos o mesmo numero de ocasiões

No mesmo ano de 1978, fuı pela prumeira vez a uma reunıão da Assocıação Brasıleura de Antropologı ( $A B A$ ), realızada no Recıfe Esta reunıão esta na hıstórıa da Associação, devıdo às profundas mudanças 
pelas quaıs ela veıo a passar a partır dalı Até então a sucessão na ABA era decıdıda exclusivamente pelo conselho, como os membros deste sendo os únıcos eleıtores da Assocıação Recordo que havıa um presıdenciavel - cujo nome não pronuncio - que gestıonava para ser alı mesmo entronızado pelo processo eleitoral citado Lembro tambem que Sílvıo - assım como Manuela Carneıro da Cunha - fazıam parte desse conselho Presenciel algumas dıscussões calorosas então no Recife - nos intervalos das reunióes do Conselho -, incluundo esses dois colegas e outros, nas quaıs a llegitımıdade do processo de sucessão em vigência na Associação era claramente evidenciada Foı esse conselho do qual Sılvio fazıa parte extremamente atıva, que deu começo a mudança do processo eleıtoral na dıreção do voto universal dos socıos hoje vigente na ABA O presıdenciável que esperava ser entronızado naquela reunıão felızmente não o fol, e a nova dıretoria da Associação alı eleita sendo constıtuida por Luız de Castro Farıa, Yonne de Freitas Leite e Alba Zaluar Foı esta duretona que realızou a transıção para o processo do voto universal dos socios

Em 1980, a convite de Sılvıo, partıcıpei do encontro, O Índıo Perante o Direito, que o então Programa de Pos-Graduação em Ciênclas Socıals da UFSC, sob sua direção, sedıou² O encontro reunıa um grupo sıgnifıcatıvo de antropologos e advogados em Florıanopolıs Ele resultou em um livro (veja Coelho dos Santos, org 1982) - no qual se incluiu um texto meu (veja Menezes Bastos, 1982) - e em uma ımportante artıculação entre as duas categorıas profıssıonaıs, que era até então muito tênue - senão inexistente - no Brasıl $\mathrm{O}$ aprofundamento dessa artıculação foı extremamente decısıva para as mudanças envolvendo a sıtuação jurıdıca do índıo no País, que vieram a culmınar na Constıtuıção de $1988^{3}$

Minha vinda para Florıanópolıs nunca terıa acontecıdo caso Sílvı não tıvesse me alertado para o concurso de professor assistente, em 1983, através do qual ungressel na UFSC, em março de 1984 Dessa epoca em dıante, nossas relações foram se tornando cada ve $\angle$ maıs próxımas Sílvı exercendo no grupo que pouco a pouco se formava na dıreção da constltuıção do programa de hoje uma insofısmavel lıderança Essa lıderança sempre esteve assentada na virtude que ele sempre demonstrou ter no 
desempenho de seu papel de por assum dızer anfıtraão do grupo Ele era um intelectual de grande prestígı local - na UFSC, em Florianopolıs, em Santa Catarına -, e igualmente forte no plano nacional Recorde-se que a 9a Reunı̃o Brasıleura de Antropologı - consıderada a reunão de renascimento da $\mathrm{ABA}$ - somente pode acontecer, e exatamente em Florıanópolıs, "graças aos esforços de Manuel Diegues Jr, presıdente eleito em 1966, e de Súlvio Coelho dos Santos"4

\section{Notas}

1 Trate brevemente dessa Primavera da FUNAI em meu texto de I998 bem como de seus tenebrosos invernos posteriores

3 O Programa de Pos Graduação em Ciencıas Socıaıs fol criado em 1978 e englobava as areas de Antropologia Sociologia e Pohtica O PPGAS data de 1985

3 Em 1983 tambem a convite de Sílvıo tomel parte em um segundo encontro em Florianopolis sobre a mesma tematica (veja Coelho dos Santos e outros orgs 1985)

4 Conforme o sitio da ABA (http //www abant org br/) entrada referente a Historico acessado em $03 / 12 / 2008$

\section{Referências}

MENEZES BASTOS Rafael Jose de Sobre a noção de tutela dos povos e indıviduos indıgenas pela Unıão In SANTOS Sílvio Coelho dos (Org ) $O$ ind to perante o Diretto ensaios Florianopolıs Ed da UFSC 1982 p 5160

MENEZES BASTOS, Rafael Jose de Saudades do General Ismarth? Notas sobre a Partıcıpação da ABA no Recem Instalado Conselho Indıgenısta da FUNAI Boletım da $A B A$ n 30 p 10121998

SANTOS Silvio Coelho dos (Org) O indio perante o Diretto ensaios Floriano polis Ed da UFSC 1982

SANTOS Silvio Coelho dos (Org) Sociedades indigenas e o Diretto uma ques tão de direitos humanos ensaios Florianopolıs Ed da UFSC 1985 